\title{
SZÜRKEVIZEK HATÉKONY KEZELÉSÉT TÁMOGATÓ DETERGENS- ÉS FÉMANALITIKAI VIZSGÁLATOK
}

\section{INVESTIGATIONS OF DETERGENTS AND METAL COMPONENTS FOR SUPPORTING THE EFFECTIVE TREATMENT OF GREYWATER}

\author{
Lós Réka ${ }^{1}$, Izbékiné Szabolcsik Andrea ${ }^{2}$, Bodnár Ildikó ${ }^{3}$ \\ Debreceni Egyetem, Müszaki Kar, Környezetmérnöki Tanszék, Debrecen, Magyarország \\ ${ }^{1}$ losrekaaa@gmail.com \\ ${ }^{2}$ szabolcsikandi@eng.unideb.hu \\ ${ }^{3}$ bodnari@eng.unideb.hu
}

\begin{abstract}
The aim of our research was to investigate the detergent content and several micro and macro elements in greywater samples, a necessary step in determining the water quality for the further reuse of the greywater. We determined the anionic detergent content of synthetic greywater with a two-phased titration method prepared in laboratory conditions. The current study leads to a new suggestion for a more accurate and reliable titrimetric method for determination of anionic detergent content of synthetic greywater samples. Following these investigations, we also examined the metal content of synthetic bath water. We wanted to highlight how detergents in greywater influence the micro and macro element content of the given synthetic bath water samples.
\end{abstract}

Keywords: greywater, detergents, micro and macro elements.

\section{Összefoglalás}

Kutatásunk célja a szürkevizekben található detergenstartalom és számos mikro- és makroelem vizsgálata, melyek meghatározása a szürkevizekben további újrahasználat miatt szükségszerü. Laboratóriumi körülmények között előállított szintetikus fürdővizek anionaktívdetergens-tartalmát vizsgáltuk kétfázisú titrimetriás módszerrel. A korábbi módszerfejlesztéseinken túl jelen tanulmányban további fejlesztéseket javaslunk a módszer pontosabb és megbízhatóbb használata érdekében. Ezen vizsgálatainkat követően a szintetikus fürdővizek fémtartalmát is vizsgáltuk, a vizsgálatok során arra szerettünk volna rávilágítani, hogy a detergensek milyen mértékben befolyásolják az adott szintetikus fürdővíz mikro- és makroelem-tartalmát.

Kulcsszavak: szürkevizek, detergens, mikro- és makro elemek.

\section{Bevezető}

Vizeink mennyiségének csökkenése, illetve az egyre növekvő vízigények jelentős problémákat okozhatnak a megfelelő minőségű víz biztosításában. Ezért alternatívákat kell kidolgoznunk, hogy csökkentsük a nagymértékű vízhasználatot. Egy lehetséges alternatíva, ha a háztartásokban például WC-öblítésre, öntözésre vagy autómosás- ra szürkevizet használunk ivóvíz helyett [1, 2]. Szürkevizeknek tekinthetők a háztartásokban mosogatás, mosás, kézmosás, fürdés során keletkező szennyvizek, melyekhez nem soroljuk a vízöblítéses WC-k vizeit [1, 2]. A szürkevizekben nagy mennyiségű felületaktív anyag található, amelyet felhasználás vagy vízbázisokba történő kijuttatás előtt szükségszerű eltávolítani, ugyan- 
is ezek az anyagok habréteget képezhetnek a víz felszínén, ezzel csökkentve a vízben oldott oxigén mennyiségét és az öntisztulási folyamatokat. Emulgeáló hatásukból adódóan gátolják az oldhatatlan szennyezők kiülepedését, így költségesebbé teszik az ivóvíz előállítását felszíni vizekből [2]. A detergenseket kémiai szerkezetük szerint 4 csoportba sorolhatjuk, eszerint megkülönböztetünk anionaktív, kationaktív, nemionos és amfoter detergenseket [3, 4]. A detergensek antropogén eredetű környezetbe jutása káros lehet, mivel meggátolják az oxigén diffúzióját a vizekben, illetve algavirágzást okozhatnak [2]. Zavarják a szennyvíztisztítást, az ivóvíztisztítást, rontják a felszíni víz öntisztulásának a hatásfokát. A szintetikus fürdővizek változatos összetételűek, ez a különbözőség a víz fémtartalmára is jellemző. A detergensek jelenléte mellett számolnunk kell a használt vizek mikro- és makroelem-tartalmának növekedésével, mivel nagy koncentrációban találhatóak nyomelemek és nehézfémek is ezen frakciókban, melyek újrahasználat esetén jelentős terhelést gyakorolhatnak az ökoszisztémára [1, 5, 6]. Vizsgálataink során a szürkevizekben található különböző makro- és mikroelem-koncentrációkat is vizsgáltuk, hogy megállapíthassuk, a szürkevizekben található detergensek hogyan befolyásolják ezen elemek koncentrációit.

\section{Anyag és módszer}

A Környezetmérnöki Tanszéken évek óta folyó kutatások során adekvát mérésekkel is sikerült bebizonyítani, hogy a szürkevizek minősége (öszszetétele) nagyon változó. Ezért kidolgoztak egy szintetikus szürkevízreceptet, mely jól reprezentálja a régióban keletkező átlagos fürdővízmintákat. Az így fejlesztett állandó összetételű szintetikus szürkevízzel többek között a detergenstartalom meghatározására szolgáló módszerfejlesztési kísérleteink eredményei is jól összehasonlíthatók egymással. Kutatásunk célja a szürkevizek detergenstartalmának meghatározására szolgáló módszer alkalmazhatóságának vizsgálata, fejlesztése volt, mely segítségével olyan egyedi módszert dolgozzunk ki, mellyel a szürkevizek detergenstartalma gyorsabban, pontosabban és kevésbé környezetszennyező eljárással mérhető legyen egy egyszerű titrimetriás vizsgálat segítségével. A vizsgálatok alkalmával csak az anionaktív detergensek (röviden ANA-tartalom) meghatározását tűztük ki célul, melyeket az ISO 2271:1989 nemzetközi szabvány segítségével végeztünk el. Vizsgálataink során 5 méréssorozat eredményeit

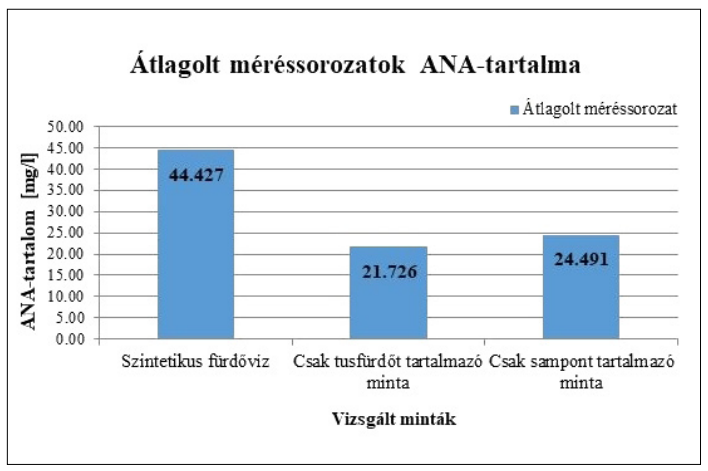

1. ábra. Szintetikus fürdővíz minták anionaktív detergenstartalma

átlagoltuk. Detergenstartalom meghatározására 3 vízmintát készítettünk, elsőként a laboratóriumilag előállított fürdővizet vizsgáltuk, melynek ANA-tartalma $44,427 \pm 1,59 \mathrm{mg} / \mathrm{L}$, a csak tusfürdőt tartalmazó vízminta esetén az ANA-tartalom $21,726 \pm 0,39 \mathrm{mg} / \mathrm{L}$, a csak sampont tartalmazó vízminta ANA-tartalma 24,491 22,00 mg/L-nek adódott, melyet az 1 . ábra szemléltet.

Megállapítottuk, hogy a csak tusfürdőt és csak sampont tartalmazó minták ANA-értékeit összeadva megközelítőleg megkaptuk a szintetikus fürdővíz ANA-tartalmát, ami azt mutatja meg, hogy a háztartásokban főként a kozmetikai szerekből, tusfürdőkből és samponokból származik a fürdővíz ilyen jellegű detergenstartalma. Fémanalitikai mérések során mikrohullámúplazmaatom-emiszsziós spektrometriát, röviden MP-AES mérőmüszert használtunk, mely méréseket a Debreceni Egyetem Szervetlen és Analitikai Kémiai Tanszékén található Agilent 4210 MP-AES-készülékkel végezhettünk el. Ezen méréstechnika alkalmazása során az elemeket egymást követően tudjuk mérni [7]. A készülékben az elemek mérése egy mintából egymás után történik, hullámhossz szerint növekvő sorrendben. A nagyszámú hullámhossz-adatbázis lehetővé teszi a megfelelő hullámhossz kiválasztását, ezzel minimalizálva a spektrális zavaró hatásokat.

\section{Eredmények és értékelésük}

Kutatásunk során vizsgáltuk a szintetikusan előállított fürdővizek mikro- és makroelem-tartalmát. Célunk az volt, hogy megvizsgáljuk a detergensek milyen mértékben változtatják meg az adott elemek koncentrációértékeit. A mérések alkalmával kontrollként a minták készítéséhez használt ivóvíz mikro- és makroelem-tartalmát is mértük, ugyanis a későbbiekben ezen eredmé- 
nyeket is összehasonlítottuk a szintetikus fürdővízmintákra kapott eredményeinkkel.

A 2. ábra a bárium-, réz-, stroncium- és cinktartalmat szemlélteti.

A 3. ábrán az az alumínium-, kadmium-, krómés vastartalmak láthatóak.

A lítium, mangán, nikkel és ólom-koncentrációkra vonatkozó adatokat pedig a 4. ábra mutatja

Mikroelemek vizsgálatai során megállapíthatjuk, hogy a réz-, cink- és nikkelelemek koncentrációemelkedéséért jelentős mértékben felelősek a detergensek. Ólom esetén azt tapasztaltuk, hogy a detergensek mellett a szintetikus fürdővízhez szükséges egyéb alkotók is befolyásolják ezen mikroelem-koncentráció növekedését. A vas, alumínium és lítium mikroelemek esetében elmondhatjuk, hogy a szintetikus fürdővíz egyéb alkotói okozhatják a koncentrációváltozásokat. Stroncium-, bárium-, kadmium- és mangántartalom már jellemzően az ivóvízmintákban is megtalálható, tehát ezen elemek mennyiségét nem befolyásolja a detergensek jelenléte. A krómtartalomra vonatkozó vizsgálatok minden esetben méréshatár alatti elemtartalmat jeleztek, vagyis a minták krómtartalma 0,1 $\mu \mathrm{g} / \mathrm{L}$ alatti értéknek adódtak, mivel az alkalmazott készülék kimutatási határa krómra vonatkozóan 0,1 $\mu \mathrm{g} / \mathrm{L}$ volt. Az 5. ábrán láthatók a vizsgált makroelem-tartalmak (kálcium, kálium, magnézium és nátrium).

Makroelemek vizsgálata során megállapíthattuk, hogy a vártnak megfelelően a kalcium és magnézium jelenléte már az ivóvízben is jelentős, azaz ezeknek az elemeknek a jelenlétét nem a detergensek okozzák, hanem az ivóvíz keménységéből származnak. A megemelkedett kálium- és nátriumkoncentrációk kapcsán elmondhatjuk, hogy a fürdővizekben található detergensek befolyásolják ezen elemek mennyiségét. Mindezek alapján az elemkoncentrációk alakulásáért is nagymértékben felelősek lehetnek a detergensek, melyek változatos tisztító-, mosó- vagy kozmetikai szerek használata miatt jutnak a szürkevizekbe.

\section{4. Összefoglalás}

Vizsgálataink során a detergenstartalom meghatározását tűztük ki célul az ISO 2272: 1989-es nemzetközi szabvány segítségével. A szintetikus fürdővíz ANA-tartalmát megállapítva azt tapasztaltuk, hogy a csak tusfürdőt és csak sampont tartalmazó ANA-értékeket összeadva megközelítőleg megkaptuk a szintetikus fürdővíz ANA-tartalmát. Megállapítottuk, hogy a háztartásokban főként a kozmetikai szerekből, tusfürdőkből és sampo-

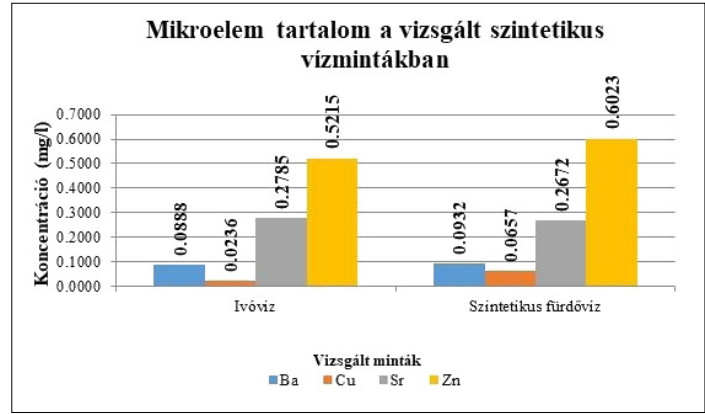

2. ábra. Vizsgált vízminták bárium-, réz-, stronciumés cinktartalma

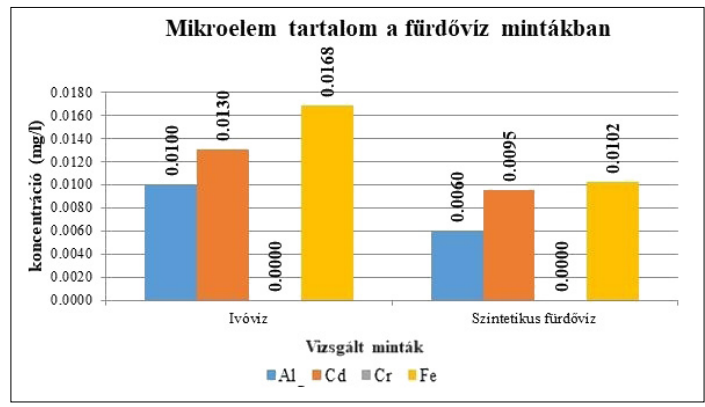

3. ábra. Alumínium-, kadmium-, króm-, vastartalom a szintetikus fürdővízmintákban

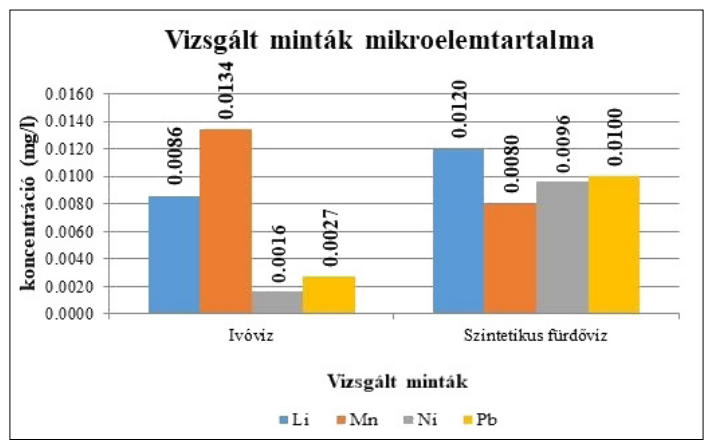

4. ábra. Lítium-, mangán-, nikkel- és ólomtartalom a vizsgált fürdővízmintákban

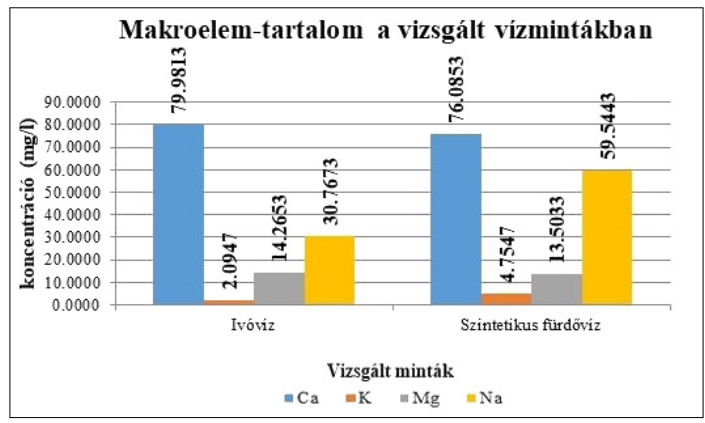

5. ábra. Makroelem-tartalom a szintetikus fürdővízmintákban 
nokból származik a fürdővíz detergenstartalma. Mikroelemek esetén a cink-, réz-, nikkel- és ólomelemek koncentrációiban okozott a detergensjelenlét elemkoncentráció-növekedést. Cink esetében teljes mértékben, réznél kb. 80\%-ban, míg nikkel és ólom esetén kb. 30\%-ban okozták a detergensek az elemnövekedéseket. Makroelemek vizsgálata során a nátrium- és káliumelemek koncentrációi változtak a detergenshasználattal. Nátriumtartalom alapján 30\%-ban, kálium esetén 60\%-ban a detergensek felelősek a megnövekedett elemkoncentrációkért.

\section{Szakirodalmi hivatkozások}

[1] Ghaitidak D. M., Yadav K. D.: Characteristics and treatment of greywater. A review. Environmental Science and Pollution Research, 20/5. (2013) 2795-2809.

[2] Lós R., Izbékiné Szabolcsik A., Bodnár I.: Szürkevizek detergens tartalmának meghatározására alkalmas analitikai módszerek fejlesztése. International Journal of Engineering and Management Sciences (IJEMS), 3/2. (2018).
[3] Juhász É, Lelkesné Erős M.: Felületaktív anyagok zsebkönyve. Müszaki Könyvkiadó, 1979.

[4] Ketola A.: Determination of surfactants in industrial waters of paper-and board mills. (2016). DOI: 10.13140/RG.2.2.36735.41124

[5] Bodnar I., Szabolcsik A., Baranyai E., Uveges A., Boros N.: Qualitative characterization of household greywater in the Northern great plain region of Hungary. Environmental Engineering and Management Journal, 13/11. (2014) 2717-2724.

[6] Bodnár I., Boros N., Baranyai E., Fórián S., Izbékiné Szabolcsik A., Jolánkái G., Keczánné Üveges A., Kocsis D.: Épületek csapadékvizeinek és szürkevizeinek vizsgálata az Észak-Alföld régióban környezetbarát és energiahatékony hasznosítás céljából. In: F. Kálmár (szerk.) Fenntartható energetika megújuló energiaforrások optimalizált integrálásával, Akadémiai Kiadó, 2014, 167-201.

[7] Baranyai. E.: Mikrohullámú plazma atomemissziós spektrometria, Debreceni Egyetem, Szervetlen és Analitikai Kémiai Tanszék, 2015. 